Portland State University

PDXScholar

7-9-1996

\title{
The Flor Metaphor of Pre-Conquest Nahuatl Literature
}

Victoria Louise Defferding

Portland State University

Follow this and additional works at: https://pdxscholar.library.pdx.edu/open_access_etds

Part of the Spanish and Portuguese Language and Literature Commons Let us know how access to this document benefits you.

Recommended Citation

Defferding, Victoria Louise, "The Flor Metaphor of Pre-Conquest Nahuatl Literature" (1996). Dissertations and Theses. Paper 5248.

https://doi.org/10.15760/etd.7121

This Thesis is brought to you for free and open access. It has been accepted for inclusion in Dissertations and Theses by an authorized administrator of PDXScholar. Please contact us if we can make this document more accessible: pdxscholar@pdx.edu. 


\section{THESIS APPROVAL}

The abstract and thesis of Victoria Louise Defferding for the Master of Arts degree in Spanish were presented July 9,1996 and accepted by the thesis committee and the department. COMMITTEE APPROVALS:

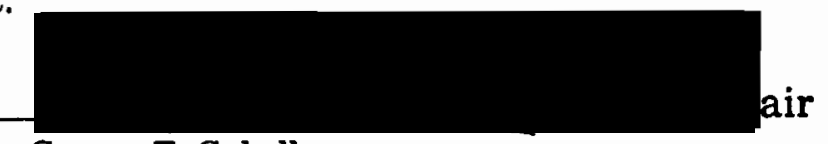

George T. Cabello

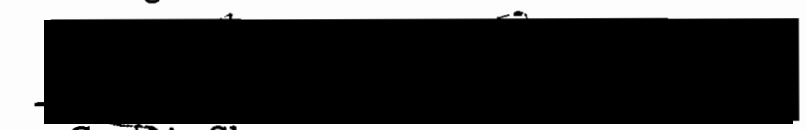

Cynthia Sloan

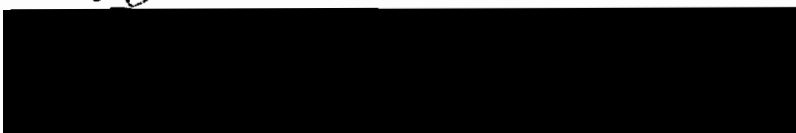

Rubén Sierra

Representative of the Office of Graduate Studies

DEPARTMENT APPROVAL:

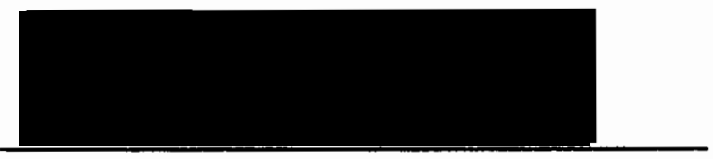

Louis Elteto, Chair

Department of Foreign Language and Literature

ACCEPTED FOR PORTLAND STATE UNIVERSITY BY THE LIBRARY by on 19 beequet 1996 


\begin{abstract}
An abstract of the thesis of Victoria Louise Defferding for the Master of Arts in Spanish presented July 9, 1996.
\end{abstract}

Title: The Flor Metaphor of Pre-Conquest Nahuatl Literature

The purpose of the present study is to show that the metaphor, flor, of Pre-Conquest Nahuatl literature means much more than the most widely accepted rendering of that metaphor that classic scholars such as Miguel León-Portilla and Angel M. Garibay have attributed to it. Typically flor is referred to as meaning poetry. It is explored in this study as a metaphor that refers to entheogenic plants, their use and the divine words or songs, or poetry, that resulted from their use. As evidence for the theory presented, I examine and discuss various religious practices and important archeological treasures in order to help us understand a broader concept of flor. I then present my findings in a purely literary context.

Gordon Wasson's study of pertinent archeological evidences is important to the foundation of this study, especially his studies of mushroom stones, figures of ecstacy and more importantly his study of the statue of Xochipilli, which can be viewed as a three-dimensional chart of the entheogenic substances used by the nobility to create their true or divine 
words.

The rhetoric the nobility used in their meditations was richly poetic, imaginative and filled with metaphors that are elusive to those not wellversed in their noble dialect. As the noble underwent an entheogenic experience, he was transported from the real world via magical flight to the ethereal world of mystical time, space and knowledge. It was there on a search for truth that he would gain wisdom from the divine and be able to express this wisdom through true or divine words in xochitl in cuicatl.

Some of the more important themes common to many of the poems studied are the mystery of life, philosophical questions and the importance of friendship.

It was found that the additional meaning that we have attributed to the metaphor flor in these poems is an adequate rendering of the metaphor. 
THE FLOR METAPHOR OF

PRE-CONQUEST NAHUATL LITERATURE

by

VICTORIA LOUISE DEFFERDING

A thesis submitted in partial fulfillment of the requirements for the degree of

MASTER OF ARTS

in

SPANISH

Portland State University

1996 
Long before Christopher Columbus landed in the New World, highly cultured groups of peoples were practicing sophisticated forms of study of the world around them. In Mesoamerica the Maya and the Nahua civilizations were two such groups whose heritage and belief systems could be traced to the even more ancient Toltec, Olmec and Teotihuacano civilizations. The conquistadores Hernán Cortés, Bernal Díaz and other chroniclers of the Conquest have given us detailed descriptions of the groups which concern us most in this study, the Nahua. Cortés and Díaz express their amazement of the high level of sophistication as compared to the European society with which they were familiar. There were established governments, forms of trade, schools, and religious and social orders. As in other sophisticated communities poetry, music and dance were an integral part of the society, so much so that in the case of the Nahua they were an important focus of the nobility. Fortunately for us today several examples of that poetry and song have survived the onslaught throughout the centuries of power-hungry warlords, greedy conquistadores, religious fantaticism and Time. These texts give us glimpses of the philosophical and religious ideas of the aristocracy. They give us insights into and knowledge of the culture.

As a modern scholar studies the poems and songs of the ancient manuscripts of Nahuatl Mesoamerica, he is often baffled by the imagery and the metaphorical language used by the ancient poet (Hernández 143). We can only surmise from the various written and archeological records we do have, 
what these metaphors may have meant to the lords of México using them. Miguel León-Portilla tells us that "what sometimes appear to be concrete details, such as flowers and song, quetzal plumage, or jade and precious stones, are metaphors used to express the most subtle and beautiful abstractions (Pre-Columbian 34)." Thelma Sullivan relates that "Nahuatl rhetoric is richly poetic and imaginative (98).” The poetry conjurs up rich images of the real world and the spirit world through the use of many metaphors that are important to Pre-Conquest Nahuatl literature. Several of the metaphors are elevated above other symbols of the language. One of the most important is that of the flor. References to flor and flor $y$ canto occur time and time again. This study is an attempt to show that the metaphor, flor, of Pre-Conquest Nahuatl literature means much more than the most widely accepted rendering of the metaphor that Miguel León-Portilla and Angel M. Garibay have attributed to it. These scholars indicate in their works that the flor / flor $y$ canto of the Pre-Columbian poetry of Mexico is a metaphor for poetry or true or divine words. This study will propose that flor is much more than a metaphor for poetry. It will be explored as a metaphor that refers to entheogenic plants, their use and the divine words or songs, or poetry, that resulted from their use. As evidence for the theory presented in this study, I examine and discuss various religious practices and important archeological treasures in order to help us understand a broader concept of 
flor. I then present my findings within a purely literary context.

Works by various early chroniclers, such as Fray Bernardino de Sahagún, Diego Durán and others are important foundations for this study. Since these works are relied upon as important to this study, their credibility will be addressed.

Durán compiled and commented on several important aspects of Aztec culture, including religious beliefs and ceremonies, commerce, the roles of the nobility and heads of state, and the everday life of a Nahua.

... fray Diego Durán que, llegado niño a México, consagró él también, desde 1550 hasta 1581 , una parte importante de su vida a coleccionar los elementos más elocuentes de la cultura azteca. Le debemos la Historia de las Indias de Nueva España e Islas de la Tierra Firme, un conjunto de datos igualmente preciosos de la cultura náhuatl. (Baudot 37)

J. Jorge Klor de Alva tells us that because Sahagún isolated descriptions from interpretations, his works seem more objective and authentic than "those of Durán, Motolinía, or Olmos, the other serious contemporary [to Sahagún] investigators of native customs (Klor de Alva "Sahagún" 44)." Sahagún's purpose in writing was to "create an appropriate instrument for preaching the Christian doctrine in New Spain (Lopez Austin "Research Method" 112)." The scope of Sahagún's work has had a far more 
reaching effect than the friar probably ever imagined, reaching into the twentieth century. Lopez Austin goes on to tell us that despite the differences and contradictions among the Sahaguntine informants and the misinterpretations made by Sahagún in spite of his knowledge of the language, he still came up with a work that very comprehensively details the Nahua society before the Conquest. "It is an encyclopedia of the Nahua people, planned and directed by Fray Bernardino de Sahagún, and formed from the material supplied by the native elders who lived fully within the world preceeding the conquest (López Austin "Research Method" 118-119)."1 Sahagún constantly searched for the best description of Nahua culture. He continuously edited the texts of the native informants. Additionally he constantly reassessed his interpretations of the language and culture and also the best way to present them (Klor de Alva "Sahagún" 33). It is important to note that one must also keep in mind the question of veracity of the native informants' testimonies. They were, afterall, exposed to EuropeanChristian ideology, and may have at times held back information from Sahagún, as well as have added to the information in order to please him.

1Although problems with misinterpretations, omissions and additions have been noted by scholars such as León-Portilla in his "Problematics" essay and López Austin in his "Research" essay, overall his ethnographic work seems to be among the most reliable and objective works that are available to us today. 
They may have given information genuinely reflecting their ancient culture, but also may have included personal reflections and attitudes (Klor de Alva "Sahagún" 46, López Austin "Research" 148). Evidence of later revisions of his work show us that he was well aware of the problem of using Native informants and also of the paradox of fitting the Nahua culture into Christian categories. His greatest dilemma perhaps was that the more details he gave, the more the text could be useful for eradicating idolatrous beliefs and practices, thus fulfilling his original intention of creating a work that could be used in the Evangelization of the indigenous peoples; but, in turn, the additional details helped to further legitimate the integrity of the culture and defeat "christianization." And so the vicious circle continued (Klor de Alva "Sahagún" 38, 46). Even though this created a difficulty for Sahagún in completing his work and for us today in interpreting his work, the Sahaguntine corpus remains as one of the most reliable texts we have. "They are [the works of Sahagún] ... the most thorough, objective and complete study ... and an indispensible basis for knowledge about the Aztecs (Ortiz 17).

This present study is not the only work to rely on the Sahaguntine texts. Several investigators have benefited from Sahagún's works, such as Phillip II's physician, Doctor Francisco Hernández, Fray Gerónimo de Mendieta, Juan Suárez de Peralta, Diego Muñoz Camargo, Fray Juan de 
Torquemada and Antonio de Herrera. Others have used Sahagún's works in their writings as well (León-Portilla "Problematics" 235-6). "La obra de fray Bernardino, linguística y filológica a la vez, sigue siendo fuente inapreciable para cuantos se acercan al idioma y la cultura del México antiguo (A.H. de León Portilla XXIII)." Since the Sahaguntine texts were credible enough for such scholars as those stated above, they remain a reliable source for this study for Sahagún not only studies Pre-Conquest Aztec life, language, and culture, but also includes exhaustive descriptions of plants and flowers that are important to our study of the flower metaphor.

As Sahagún shows us, flowers have been an important part of the cultures of Mesoamerica since ancient times. They abound throughout the region.

... la riqueza del país que gracias a la fertilidad de la tierra reúne una gran variedad de plantas. Mucho antes de la conquista, los aztecas comenzaron a reunir las plantas, a ensayar sus virtudes, a agruparlas según sus propiedades médicas o sus afinidades botánicas. (Rodríguez 54)

Rodríguez continues his eloquent discourse giving us various details on the importance of flor in the Nahua culture.

... no hay nada como sus ciudades-jardines, estas chozas perdidas entre la verdura, el atrio de la iglesia ornado con 
hermosas plantas, esta profusión de flores en el mismo templo. ... Los comerciantes pedían flores de provincias lejanas ... los guerreros mismos, en el curso de sus expediciones, recojían ávidamente las especies desconocidas en la metrópoli en donde eran consideradas como artículos de lujo ... se ofrecía a los Grandes y a los Embajadores extranjeros, guirnaldas de flores. Aparecer en público con un ramo en la mano, era una distinción social, una marca de nobleza, y aun ciertas plantas no podían servir sino a los principales de la nación, y otras solamente al Monarca. ... Ninguno era admitido en presencia del rey sino llevaba en las manos un ramo fragante. La misma etiqueta se exigía en los templos, porque los ídolos debían ser profusamente adornados de flores. . . Para estar siempre bien provistos, los aztecas imponían a los pueblos sometidos, tributos de flores.

The passion for and prevalence of flores in the Nahua culture is evident in the many representations of flowers, plants, trees and mushrooms in various surviving artifacts, including the ruins of ancient cities such as Teotihuacan and various statues, such as that of Xochipilli, commonly known as the God of Flowers. A number of codices, such as the Florentine codex and others and the works of various chroniclers, such as Sahagún and Durán, show 
us that these plants were not only beautiful or fragrant, but they were very important to the lords of Mexico (Sahagún Book 6 256). Some were highly prized for their medicinal and psychoactive properties (López Austin Sahagún's Work 221). The informants of Fray Bernardino Sahagún evidently were well aware of various psychoactive plants, or as we will refer to them throughout this work, entheogenic, or god within us, plants. Gordon Wasson, who has done extensive world-wide research on entheogens, tells us that these entheogenic plants were considered to be endowed with mystical powers by the ancient cultures using them. They were used as a means to touch the divine. Through the visions induced by the entheogens the Nahua user believed he could probe the world of the gods. He could see divine images, hear divine sounds and thus create divine words or compose divine songs. The Nahua informants gave detailed, but sometimes cautious, descriptions which Sahagún wrote down in what is now the eleventh book of the Florentine codex. He also included some drawings. Several of the drawings included are of various entheogenic nanácatl, mushrooms. One of the drawings displays a costumed man that seems to be communicating with a god through the use of the divine mushrooms that he is standing on, or at least he is enjoying the entheogenic experience he is having due to the ingestion of the mushrooms he is standing on (Book 11 plate 516). Chapter seven of the codex specifically deals with herbs, plants, seeds, flowers and mushrooms that inebriate. 
Named are various plants that are considered to be psychoactive and are the entheogens or flor of Nahuatl literature. Included in this group of entheogens are ololiuqui (Florentine codex plates 566 and 581), teonanácatl, xochinanácatl, poyomatli and peyotl, the common tobacco plant, as well as cacao and the chocolate drink derived from it, cacaoatl. Sahagún's record mentions many more plant materials that were used for their psychoactive and medicinal powers. The discussion in this study will be limited to the above mentioned substances.

To begin a discussion of the interpretation of flor in Nahuatl literature one must begin considering the significance of flor in the religion of the society and the daily lives of the Nahuas. From studying the various manuscripts or codices that are still available to us today, one learns that religion influenced many aspects of the Nahuatl society. Religious codes controlled public and private lives. It regulated commerce, politics, war and even sports, such as el juego de pelota, which had some very important religious ramifications dealing with worship, life, death and the afterlife. Bernard R. Ortiz de Montellano describes the Aztec religion as "an ecclesiastical state institution (10).” All activities, whether public or private, even to the extent of raising children and doing household chores, were thoroughly permeated with religious thoughts and practices. The gods were to be revered, obeyed and feared in all aspects of life. The gods were responsible for flowers, life and death and all other 
dualities. "El aprender a mar a los dioses significaba comprender que ellos eran responsables de la muerte y de las flores. Que ellos eran la dualidad, la unión de los contrastes, que eran causa del dolor y de la delicia, de lo blanco y de lo negro, del día y de la noche (Díaz 42)." In his work Historia de la literatura nahuatl, Angel M. Garbay has presented six principles gleaned from the work of Alfonso Caso that bear repeating here to further emphasize the importance of religion in the lives of the Aztecs. ${ }^{2}$

I. “Tan grande era la importancia que tenía la religión para el pueblo azteca, que podemos decir sin exageración, que su existencia giraba totalmente alrededor de la religión." II. “No había un solo acto de la vida pública y privada, que no estuviera teñido por el sentimiento religioso.”

III. "La religión era el factor preponderante e intervenía como causa hasta en aquellas actividades que nos parecen a nosotros más ajenas al sentimiento religioso, como los deportes, los juegos y la guerra.”

IV. “Regulaba el comercio, la política, la conquista.”

V. "Intervenía en todos los actos del individuo, desde que nacía hasta que los sacerdotes quemaban su cadáver y enterraban sus

2The principles are from Caso's work, La religion de los aztecas. The numerical values were added by Garibay. 
cenizas."

VI. Era la suprema razón de las acciones individuales y la razón de estado fundamental." (Garibay Historia 107)

From these principles we see a people whose daily lives are so pervaded by religion that there is absolutely nothing done that is not influenced by it. "Religion in the primitive society was an awesome reality, 'terrible' in the original meaning of that abused word, pervading all life and culminating in ceremonies that were forbidden to the profane (Wasson "Hallucinogenic" 148)." It is the greatest purpose for one's existence. The following words are from some sabios aztecas in defense of their religious beliefs.

Era doctrina de nuestros mayores que son los dioses por quien se vive ellos nos merecieron (con su sacrificio nos dieron la vida) ¿En qué forma, cuándo, dónde?

Cuando aún era de noche...

Nosotros sabemos

a quien se debe la vida,

a quien se debe el nacer,

a quien se debe ser engendrado, a quien se debe el crecer, como hay que invocar, 
como hay que rogar ... (Díaz 35)

With these sabios' words one is able to understand that Religion was all important to the Nahua. Everything he did during his lifetime revolved around the state's formal religion.

This society was so fully entrenched in its religious beliefs that Religion ordered and controlled the society in very strict ways. Again we look at the works of various early scholars for our information. Among the most outstanding are the aforementioned Sahaguin and Diego Durán, as well as the more contemporary researcher, Alfonso Caso. From them we learn that not only everyday lives, but government, politics, commerce, war, and religion were controlled by rigorous codes. There is a wealth of information regarding the many codes, laws and punishments of the Aztecs in Diego Durán's work entitled, Book of the Gods and Rites and the Ancient Calendar. The people were expected to adhere to very strict legal and moral codes. Disobedience required harsh punishments which often included slavery and/or death. Cortés in his Cartas de relación, as well as Durán in his work, relates that the market places were very well organized and ordered. The gods were to be honored and revered. All ceremonies and rites were to be fulfilled without exception. All elders regardless of social or economic position were to be honored and revered. Murder was prohibited as well as adultery, thievery, and lying. Public drunkenness was prohibited. However, an interesting 
footnote to the harsh rules and regulations and their prescribed punishments is that every four years at the Feast of Tezcatlipoca, a general pardon was granted. According to Durán this was a feast of confession, repentance and pardon (Book 95-97). So even in a highly regulated society whose people were severely admonished, there was a place for pardon.

The use of psychoactive substances such as the hallucinogenic plants, including teonanacatl and ololiuqui, were approved by the State's religious leaders for use by the aristocracy, but, were highly controlled (Gruzinski 216). In addition it seems that the use of these entheogens were permitted only on certain occasions, for example, they were used at the coronation of Moctehzuma II. They were not for general public use. As long as one adhered to the beliefs, codes, rituals and ceremonies mandated by Religion he was "free" to live out his life.

The Religion of the State had very tight controls on all subjects, including the nobility and the priesthood, and on virtually all activities. Various requirements for the diverse ceremonies and rites included the use of many different flowers and plant materials. Not a few of these were psychoactive in nature and had a very high purpose within particular rites and rituals. The Nahuas did not regard these hallucinogens as drugs in the same sense as some do in modern society. That is, the view that these were recreational substances or escape mechanisms from one's problems was a 
totally foreign idea to the Nahua. The idea of abuse was virtually unknown and dealt with quickly and severely, if it did occur. To the Nahua these were very sacred substances. They were regarded as something wondrous, something miraculous, beyond explanation and comprehension. They were a gift of nature, if not a gift from the gods themselves (Wasson Wondrous 81). Abuse was not allowed, nor tolerated at all.

The forerunners of the Aztec people had discovered, perhaps about 4,000 years ago, plant materials with certain transcendental qualities and according to the archeological evidence of mushrooms stones that have been found, they may have had a cult built up around the worship of the mushroom and its strange properties (Wasson Teonanácatl 69). These people had discovered that perhaps these plant materials that altered one's state of mind, might be an avenue to gain true knowledge of one's god(s); to perhaps be the path to commune with the god, thereby receiving divine inspiration for one's art forms, in this case, poety and dance. The consumer would be transported on a "magical flight to mythic time and space (Ortiz 69)." In their thinking a human being in and of himself is not capable of communing with $\operatorname{god}(\mathbf{s})$. But by ingesting mind altering flowers, mushrooms and other plant materials known as entheogens, he is elevated to a higher state where communication and the search for truth may be possible. Only in his ecstatic state does he enter into the world of the gods. Gruzinski tells us that by 
partaking of the entheogens, the Nahua entered into contact with the world of the gods and esoteric knowledge (214). "One cannot truly comprehend "reality" unless one sees both the real world and the mythic world as perceived in an altered state of consciousness (Ortiz 69)." The intoxication that insued upon ingestion of the substance was considered sanctified. This was a most holy act. "Delirium was a holy condition, a sacred communion with the deity (Gruzinski 214).”

This communion with the gods was not only for the priesthood, but also sought after by the nobles, who were not only the warriors of the society, but also the philosophers, the poets and the artists. These, then, were this society's appointed communicants with the gods. Under prescribed circumstances, they partook of the sacred flor substances to commune with divinity. It is reasonable to expect that a special word signifying all entheogens would be used within the highly metaphorical language of the nobles for their rhetoric was very rich and imaginative (Sullivan 98). This word in the Spanish translations of the literature is flor. Flor as a metaphor for entheogens also became attached to the word cantos.

“El nombre mismo que se usa en náhuatl para designar un poema: cuicatl, significa también canto, música o canción y la poética se confundía con el arte musical, bajo el nombre de cuicatlamatiliztli. El poeta era el canto: cuicani, y el sistema de 
escritura prehispánico representaba su actividad con el signo normal de la palabra: la voluta, pero una voluta decorada con flores, una "palabra florida," en cierto modo. (Baudot 49) The cantos were a direct result of the entheogenic experience of the singer (poet). Song, music, flower and dance were all integral to the singer's (poet's) experience. He was able to express himself through song (poetry) because of the truth seen in his entheogen induced visions. Simply put, he had something very special and unique to sing about because of his mind altering adventures. His hallucinogenic visions took him to the mysterious realm of the gods. His poetry was the vehicle he used to express to others the divine thoughts he received during his ecstatic state. León-Portilla calls the mythical poems "an art which joins the concrete and abstract, the real and the fantastic (Pre-Columbian 34)." Through poetry, the poet joins his life on earth to the mystical, enigmatic realm of the gods. It is therefore very reasonable that the symbol representing the high art of speaking with divine words or song (poetry) came to be flor. Flor and flor $y$ canto, then, not only represent the entheogenic substances, but also simbolize the divine words spoken and created under their influence.

The poets, these wise sages or masters of the spoken word, as LeónPortilla calls them, were very intent on being able to compose poetry of true, divine words, or flor $y$ canto. To speak the divine words, or poetry, which 
became known as flor $y$ canto, the noble ingested the psychotropes. He believed that the hallucinogenic flowers and other plants aided him in this endeavor.

La poesía....parece como elemento fundamental en las celebraciones ceremoniales. Incluso, la elaboración poética podía estar directamente ligada a las necesidades del rito religioso, dicha y pensada en gran parte para invocar a la divinidad, en un pueblo cuya religión era omnipresente. (Baudot 51)

Poetry was "wholly religious, created by poet-kings who believed that flower and song (xochitl in cuicatl) were the media by which the gods spoke to men. Poets, they said, were the spokesmen of the gods, poetry a revelation (Nicholson A Guide 7)." This "communication" was made possible by the use of entheogens. The gods spoke to men during the entheogenic episode. The songs were a result of this encounter with the gods.

Mexican Indians seem to regard the hallucinogenic plants, whether mushrooms, peyotl or morning glories, as mediators with god, not as a god. The Nahua-Aztecs and other groups speaking the same tongue called the mushrooms teo-nanacatl, 'god's flesh,' but the mushrooms do not figure in their pantheon. (Wasson SOMA 3)

Flor $y$ canto as a phrase in literature that refers to the poetry, the 
songs, the divine words or that which is true is an important metaphor for the entheogens and the altered state that they create. Flor is obviously tied to the diverse flowers, plants and entheogens that gave the nobles a means of going beyond themselves into the realm of the gods. "Flowers, which are the reproductive part of the plant, into which it pours all its exuberant overflow of colour and scent, these, to the Nahuas, were simply the visual equivalents of song (Firefly 95)." But, as submitted in this study, this refers to not only the visual, but the experiential as well. They not only enjoyed the outward beauty of the various flowers and plants, but also reveled in the holy experiences provided to them by ingesting various entheogens.

Canto represents the resulting song or poetry that was accompanied by various instruments, including drums, rattles, shells and flutes. "Entheogens also produce auditory effects that can take the form of music. Therefore, the second word of the Aztec two-word metaphor for poetry, cuicatl ("song"), may also refer to the effects of entheogens (Ortiz 70)." Flor $y$ canto are "artistic expressions in the forms of words, songs, and paintings that connected the human personality, referred to as "face and heart," with the divine (Carrasco 80)." The connection between the human personality and the gods which granted the creativity was through the use of the gifts, the entheogens, given to the Nahuas by their gods. The full meaning of reality can only be perceived under the influence of entheogens (Ortiz 70). 
One master of the spoken word, Tecayehuatzin, invited several other nobles to discuss the true meaning of flor $y$ canto. "Aqui en Huexotzinco he convocado esta reunión. / Yo el señor Tecayehuatzin, / he reunido a los príncipes...(León-Portilla Cantos 152).” Tecayehuatzin probably served tobacco and cups of cacaoatl or agua de cacao to his guests, as it was customary to do so at such gatherings of the nobles (León-Portilla PreColumbian 81). The theme of this conference was to discuss the true meaning of flor y canto, poetry, art and symbolism.

He [the host, Tecayehuatzin] asks about the origins of flowers and songs. Is it possible to say true words on earth, he asks, or is it man's destiny to search continuously, sometimes thinking he has found what he yearns for, but in the end going his way and leaving behind only the memory of his songs? (León-Portilla Pre-

\section{Columbian 81)}

The discussion takes several directions as each poet-philosopher tries to answer Tecayehuatzin. Some view art and symbolism as gifts from the gods, but don't know if they exist in the afterlife. Some view flowers and song as the way to invoke the Dador de la vida. Others pose questions regarding the meaning of truth and existence here on the earth. Then one philosopher gives his opinion that flower and song is like the "flores que embriagan." León-Portilla uses the phrase hallucinatory mushrooms for the flowers that 
intoxicate. He suggests that what this poet, Xayacamach of Tlaxcala, is saying is that:

flower and song, poetry and art, like the hallucinatory mushrooms, are the best means of intoxicating the heart and forgetting our sadness. Those who eat mushrooms in religious gatherings see marvelous visions, ephemeral forms of many colors, more real than reality itself. (León-Portilla PreColumbian 82)

León-Portilla is very close to saying that flor $y$ canto is tied directly to the hallucinogenic mushrooms, but he stops short of doing so. This study suggests that Xayacamach is not necessarily talking about a figurative intoxication as per León-Portilla, but a literal intoxication caused by the "standing flowers," the sacred mushrooms, teonanacatl. His very being is very literally intoxicated. He is experiencing the visions of vivid colors and forms so real to his senses.

Todos de allá han venido, de donde están en pie las flores. Las flores que trastornan a la gente, las flores que hacen girar los corazones, han venido a esparcirse, han venido a hacer llover 
guirnaldas de flores,

flores que embriagan. (Cantos159)

Wasson relates to us his first-hand experience of these entheogenic voyages taken by the Nahua nobility so long ago. In an article for Life Magazine, he describes the ecstatic state brought on by ingestion of teonanacatl.

I was seeing visions, for the effect of the mushrooms is to bring about a fission of the spirit, a split in the person, a kind of schizophrenia, with the rational side continuing to reason and to observe the sensations that the other side is enjoying. (109)

Wasson and his companion took notes during the entheogenic experience, noting that his body was "inert and heavy, but [his] senses [were] floating free in space ... (Wasson Life 110)." He and the others were responding with their senses to the chanting, dancing and rhythmic clapping that were going on around them. He refers to hallucinations that were aural as well as visual (Wasson Life 109).

In the above quoted portion of the poem, Xayacamach is reminding his fellow noblemen that the entheogens are the means of reaching into the realm of the divine. The Natives of today typically respond likewise when asked about the effects of the divine mushrooms. They respond that they are carried to where their god is. "Le llevan ahí donde Dios está (Wasson Life 114)." 
Their songs have meaning because of the glimpses of truth provided by the "standing flowers," or entheogens, or more specifically here, divine mushrooms. Their songs help them forget their sadness on this earth because the entheogens have taken them from the mundane to the divine. Their songs are a reflection of the experiences that they have had while under the influence of the entheogens.

Another poet, Monencauhtzin, speaks of the richness and happiness the flowers and songs have brought him.

Brotan, brotan las flores, abren sus corolas las flores, ante el rostro del Dador de la vida.

El te responde.

$\mathrm{El}$ ave preciosa del dios, al que tú buscaste.

Cuántos se han enriquecido con tus cantos, tú los has alegrado. (León-Portilla Cantos 158)

He exclaims that the flowers are bursting forth and opening before the face of the Giver of Life. After a rain, mushrooms seem to shoot or burst out of the ground. This happens very quickly. The cells of the mushroom rapidly absorb water. Most reach their maximum height in eight to forty eight hours (World Book 942). Thus giving the impression that they have popped-up 
overnight after a heavy rainfall. It is evident from the recurrence of phrases referring to flowers that burst open that these nobles were observers of nature and had accurate knowledge about the nanacatl that burst out of the ground. The area near Popocatepetl and Cholula are known for their rich fungi production. Wasson refers to these areas as possibly being Tlalocan or Tamoanchan the place referred to in the literature as where the gods dwell (Wasson Wondrous 60). A poem talks about Tamoanchan as being the place of the gods and also the place of creation.

Arbol Florido se yergue en Tamoanchan allí fuimos creados, allí nos dio ser allí enlazó el hilo de nuestra vida aquel por quien todas las cosas viven. (Garibay Literatura 55)

Wasson and Professor Heim have found that the mushrooms, referred to as being divine, grow in this region around the volcano Popocatepetl. So when the poet says that the flowers are bursting forth before the face of god, he may literally be referring to the actual areas where the entheogens are found, or he may be figuratively referring to the communion that takes place between the noble and the divine through the use of the entheogen as he goes on to say "El te responde." The natives believe that the entheogens are responsible for the god's words in answer to the problems that have been posed by the participants of a velada (Wasson Life 109). The poet then 
continues to praise how much the songs have enriched them and made them happy.

Another of these poets mentions that it makes him happy to cover his house with flowers (could he be growing mushrooms on his thatched roof, or drying entheogens on his roof, or simply decorating his house?) and so the discussion continues. Many different ideas are presented and discussed. Consensus on the meaning of flor $y$ canto is not reached at this conference. As Tecayehuatzin brings the discussion to a close he makes a statement that perhaps they can all agree on since they don't agree on flor $y$ canto, and that is that we know that the hearts of our friends are true. Friendship is an important theme throughout Nahuatl literature and a fitting end to Tecayehuatzin's conference. “iSabemos que son verdaderos / los corazones de nuestros amigos (León-Portilla Cantos 162)!”

So just what is flor $y$ canto? The masters of the divine words at Tecayehuatzin's conference were at odds, or at least had differing opinions as to the meaning of flor $y$ canto. León-Portilla has said that:

there ... appears the concept of the whole within which small things become meaningful. What sometimes appear to be concrete details, such as flowers and song, quetzal plumage, or jade and precious stones, are metaphors used to express the most subtle and beautiful abstractions. Thus the mythical 
poems of the Nahuas and the Mayas point to the mysterious realm of the gods and lay the foundation for a doctrine of the world, man, and his existence in an art which joins the concrete and abstract, the real and the fantastic. (León-Portilla Pre-

\section{Columbian 34)}

León-Portilla does not say outright that the flor of literature could represent the out-of-this-world entheogens. He is exactly right when he says that what seems to be concrete details are metaphors expressing an entire different world of meaning. The link between the mythical poems and the mysterious realm of the gods is the flor, the entheogens. The real world of the human comes face to face with the mystical and fantastic world of the gods through the gifts of the gods, which are the divine mushrooms and other entheogens. Flower and song are then poetry, divine or true words, which are all metaphors for the entheogens that make it possible to commune with the gods; that make it possible to see the visions of the divine and create songs of true or divine words. According to León-Portilla, "flowers and song are symbolic of poetry and art in indigenous thinking (León-Portilla Pre-

Columbian 66)." But as this study proposes, they may also represent the entheogens that make the poetry possible As we will later discuss, the statue of Xochipilli supports this proposal. "The statue of Xochipilli tells us that xochitl could mean in Nahuatl, as a figure of speech, the entheogens and 
the incomparable wonder-world to which they invite us (Wasson Wondrous 78)."

Others, such as Irene Nicholson, John Bierhorst and Laurette Séjourné, have interpreted flor in a manner slightly different than that of Leon-Portilla, Garibay and that expressed in this study. These scholars are responsible for opening the door to other interpretations of flor.

In her works, Firefly in the Night and A Guide to Mexican Poetry, Irene Nicholson has agreed for the most part with the concept of flower and song put forth by León-Portilla, which is that flor $y$ canto refer to the poetry and songs of the nobility. Flower and song "were symbols for the power of true speech, which a man had to acquire (Nicholson Firefly 95)." She does not address the use of psychoactive plants in Mexico when she discusses flower and song. She sees flower and song as a strictly mental and spiritual exercise, if you will, the academic exercise of the day. Consequently the body of knowledge regarding entheogens is missing from her interpretations of the literature, although she does cite that among the poets mushrooms were used to induce visions, but she leaves the subject at that (Firefly 187). Nicholson does not question the use of flor as a metaphor for poetry. Her interpretation of flor $y$ canto expresses that "flower and song were poetry, the supreme symbol of communication between gods and men (Firefly 157)." She also adds an additional metaphor of flower, and that is, that flowers are warriors in the 
warrior songs (Firefly 172). To illustrate we cite a portion of the song "Eternal Perpetuity of the Sacrifice to the Sun" by an unknown poet. In this poem Nicholson interprets the flowers of the Smoking Shield as warriors of the Smoking Shield god.

They that carry the war upon their shoulders are the flowers of the Smoking Shield never, surely, never, surely, shall it pass away! (Firefly 172)

The work of John Bierhorst is mentioned in this study, not as an expert document of Nahuatl-English translation and interpretation, but as one of the studies that has opened the door to additional meanings of the flor metaphor. In his work Cantares Mexicanos Songs of the Aztecs, Bierhorst sees the flowers in several songs, he calls "ghost songs," as representing dead warriors or their spirits. The ghost songs are "prayers, uttered for the purpose of producing revenants (Bierhorst 46).” These revenants or spirits, he calls ghost warriors. He does not necessarily agree with Garibay that xochitl in cuicatl refers to poetry. He admits that xochitl because of its coupling with cuicatl and its interchangeable use, although appearing to be dissimilar, are however synonyms for song. However he does allow room for other 
interpretations as well. According to Bierhorst, Nahuatl is such a highly figurative and complex language filled with esoteric idioms and jargons that there is room for additional interpretations of the various metaphors (Bierhorst 16). This would include the important metaphors of the butterfly and the bird, as well as flor. Durán supports Bierhorts's claim that the language of the nobility is full of "obscure metaphors" in his work Book of the Gods and rites and the Ancient Calendar.

All the native lays are interwoven with such obscure metaphors that there is hardly a man who can understand them unless they are studied in a very special way and explained so as to penetrate their meaning. For this reason I have intentionally set myself to listen with much attention to what is sung; and while the words and terms of the metaphors seem nonsense to me, afterward, having discussed and conferred [with the natives, I can see that] they seem to be admirable sentences, both in the divine things composed today and in the worldly songs. (Durán Book 299-300)

Bierhorst continues with his claim that songs or flowers represent persons or spirits or ghost warriors. He dedicates the third chapter of his work to vocabulary that he believes is specific to what he calls "ghost-warrior" songs. 
Revenants are denoted as flowers and by flower names, for example, flower is rendered as xochitl, flower tree as xochicuahuitl, and cacao flower as cacahuaxochitl (Bierhorst 37).

According to Bierhorst, all of these terms, whenever they are used refer to revenants. He also states that butterflies and birds are ghost warriors. To Bierhorst the "ghost warrior" envisions the world beyond, but he does not address at all as to how the warrior does the envisioning. From his work, one would come away with the understanding that the ghost singer has the ability to see visions without any external aids, such as teonanacatl or other entheogens. He simply mentions that he is aware of Wasson's work regarding entheogens and he states that it is generally accepted as being outside the mainstream of thought (Bierhorst 122).

An example of Bierhorst's use of flor as a metaphor for ghost warrior follows:

When the Aztec poet sings, "From heaven, ah, come good flowers, good songs, he is not indulging in mere whimsy. Ghost warriors are being summoned by means of music, and as the singer intones their praises, they themselves, metonymically speaking, become the song, or "flowers," emanating from the sky - which if I have read native theory correctly, is the source of music. Simply put, the meaning is "Ghost warriors are 
descending from heaven. (Bierhorst 4)

León-Portilla would most likely respond to the same piece of poetry that the song and flowers coming from the sky would be the poetic inspiration received from the gods; that flower and song refer to poetry or true words coming from the gods. Laurette Séjourné, whose work will be discussed shortly, would suggest that the ghost warriors are spirits. Wasson and this study would suggest that the composer is invoking the god of heaven to commune with the composer by means of entheogens. The flowers, entheogens, come from heaven and the songs are a result of the entheogenic experience.

Laurette Sejourné in her work, Burning Water, likens the flowers, as well as the bird and the butterfly of the poems and artifacts, to the soul.

The soul is represented not only by the bird, but also by the butterfly and the flower.... The texts always use the flower in an entirely spiritual sense, and as we have already seen that the aim of the religious colleges was to use the flower of the body to bloom: this flower can be no other than the soul. (144)

She believes Xochipilli, commonly known as the Lord or Prince of the Flowers, to be the Lord of Souls. Séjourné notes:

As the bird, the butterfly, and the flower are the symbols for one particular divinity, it is clear that the Lord of Flowers, Xochipilli, 
must be the personification of the soul. He it is who 'has the power of giving flower', and, since he is not a god of vegetation, the flowers must be spiritual. (146)

Sejourné fails to mention any kind of connection between the flowers of the literature or the flowers of Xochipilli and psychoactive plants. She avoids a discussion regarding hallucinogenic plants that a close study of the statue of Xochipilli would elicit. She avoids discussing the flowers and plants that are carved on Xochipilli as literal or as representations of literal plants and flowers. The statue, itself, will be discussed later in this study.

Perhaps more appropriate to our discussion is the idea that flor (xochitl) represents the entheogenic and psychoactive plants that were widely used, but in a controlled manner, by the Nahuas, Mayas and preceeding indigenous cultures. For the Nahua, to be able to communicate with his gods was of the utmost importance. We have established by the use of the ancient manuscripts that psychoactive substances were used as a means for man to connect with the divine. The songs themselves have spoken of the flowers that intoxicate. "Los cuicatl o poemas, no dejan, ni uno solo, de hablar de flores, y más de uno de ellos está por completo consagrado a su elogio (Rodríguez 109)." Poetry or song, it seems, was the highly esteemed and sought after way of expressing oneself. Excellence as a speaker or a master of divine words was highly regarded. The nobles used various flowers, seeds and mushrooms as 
the vehicle to carry them to the realm of the divine. It can be supposed that therefore the ancients when composing their songs, gave honor to the psychoactive substances derived from plants by using the term flor from whence literally their visions and poems sprang forth. To agree with LeonPortilla and Garibay that flor y canto refers to divine or true words or poetry, is only part of the meaning of the metaphor. One also needs to bear in mind the very earthy, but at the same time ethereal meaning that psychoactive plants or entheogens, the god-within-us plants, would bestow on the phrase flor $y$ canto. It is with this more profound meaning, divine words aided by hallucinogens, that we continue this discussion.

To further stress the importance and significance of the use of narcotic plants by the Nahuas, one should look at the archeological, as well as the written record.

After all solutions to the complications entailed by the use of metaphor, metonymy, and synecdoche are limited by our knowledge of how the sculptural, pictographic, and alphabetic texts, upon which our representations of Nahua culture are based, permit us to understand the ways in which the natives assigned signification to their idiomatic and figurative words and phrases. Some of the semantic matrices of the culture have been uncovered by art historians applying stylistic and 
iconographic tools to decipher the carved images and painted codices. (Klor de Alva “Language” 158)

There are a number of artifacts which are important sources. These include mushroom stones, figures of ecstasy and the aforemontioned statue of Xochipilli.

R. Gordon Wasson has studied several so-called mushroom stones that have been found in Mesoamerica. The carvings of the mushrooms are complete with stems and caps. Under the cap of the carved mushroom one finds carvings of animals or humans incorporated into a stem. Several of these are photographed and included in Before Cortés (Easby plates $63 \& 64$ ). Wasson's study has led him to believe that because of the quantity of surviving mushroom stones, they must have had a very specific, practical purpose, not simply a decoration. "All art in pre-conquest Mesoamerican society, or virtually all, is inspired by religious beliefs. At that time there was no 'art for art's sake,' no genre art (Wondrous 195).” Wasson believes that these stones could have served in the making of rubber balls used in the preConquest ball game. The ball craftsmen would apply latex strips to the rounded surface of the mushroom cap of the stone, using it for a mold. Remembering that Religion permeated every activity, the act of crafting rubber balls would be no exception. "Probably the fashioning was attended by religious rites before, during and after ... (Wasson Wondrous 197)." This 
would tie the use of hallucinogenic plants and mushrooms to the Mesoamerican ballgame. The activities surrounding the ballgame, as a sacred, religious rite would also be sacred. The mushroom stones, the rubber balls, the songs used in the ballgame ceremonies would all be consecrated and considered holy. This is at least a very interesting theory that merits more research.

Several figures of ecstacy have been found. The ones that Wasson has studied are stone carvings of humans. The persons are seated with their heads tipped back and up to varying degrees. These carved images of people appear to be in some kind of trance. At least two of these figures are on display at the Museo Nacional de Antropologia in Mexico City. Wasson has carefully studied these figures and has concluded that the figures may indeed represent someone in a state of ecstacy or trance similar to those induced by the ingestion of psychoactive plants. These figures are all seated as in a stupor.

Several reclining figures with expressions of ecstasy were found by archaeologists Dudly and Elizabeth Easby. They suggested, independently from Wasson, that these figures of jade and clay "might well represent ordinary people enjoying the entheogenic experience (Wasson Wondrous 76).” Wasson's study of these figures concurs with the suggestion made by the Easby's. The figures do indeed suggest people enjoying the entheogenic 
experience.

Perhaps the most outstanding study of the archeological record that lends the most support to the written record is Wasson's study of the statue of Xochipilli, the Prince or Lord of Flowers. This statue is also on display at the Museo Nacional de Antropología. Díaz Infante gives us some information about the god Xochipilli. “ . . joven dios del maíz, derramó alegría, el amor, la recreación, el arte, los juegos y los cantos, la mímica y las artes plásticas (109)." This description of the god does not address the statue representing the god, nor the intricately carved flowers, plants, symbols and expression of the statue. Wasson has very carefully studied the floral carvings on the statue, as well as the expression of the statue.

The expression of Xochipilli is ecstatic. "The skyward tilt of the head and eyes, tense half-open mouth, jutting jaw, hands poised at different levels, crossed legs with feet almost wholly off the ground, the strain expressed by the retraction of the right big toe (Wasson Wondrous 57)." This expression of ecstacy is far more than the "quiet joy of a flower buff (Wasson Wondrous 57 58)." Through the mask that Xochipilli wears and the tenseness of his body, even a lay person can sense that here is a representation of a person in a trance-like or ecstatic state. Wasson continues his description: "This being is not with us, is in a far-off world. He is absorbed by temicxoch, 'dream flowers' as the Nahua say describing the awesome experience that follows the 
ingestion of an entheogen (Wasson Wondrous 58)."

The ecstacy expressed by this statue is probably more important to the metaphorical meaning of flor than the flower carvings all over his body. The ecstacy on this figure is the essence. Here is the work of a master, a supreme carving of a man in the midst of an unearthly experience, the formal hieratic effigy of the God of Rapture, the God of 'Flowers" (as the Aztecs put it): the god of youth, of light, of the dance and music and games, of poetry and art; the Child God, the god of the rising sun of summer and warmth, of flowers and butterflies, of the 'Tree-in-Flower' (Xochicuahuitl or Arbol Florido) that the Nahuatl poets frequently invoke, of the inebriating mushrooms (las flores que embriagan), the miraculous plants that transport one to a heavenly Paradise. (Wasson Wondrous 59)

The many and varied flower carvings covering this statue are also important features to be studied. They are a kind of map, or better still, a chart to the world of entheogens. Wasson believes that the flower carvings hold the key to the meaning of the statue and even more importantly to the metaphorical meaning of flor in the Mesoamerican culture (Wasson Wondrous $59)$.

The base of the statue is carved to represent the talud and tablero, or 
stepped, construction that is typical of Mesoamerican temples (Wasson Wondrous 57). The "flower" found on the base of the statue is not a flower but a series of six mushrooms in profile, arranged in a circle. The bottom mushroom is covered by the carving of a butterfly (Wasson Wondrous 59). Wasson calls this a mushroom emblem. His explanation of this "flower" becomes even more plausible when one remembers that this statue of Xochipilli was found on the slopes of Popocatepetl, "in the heart of the sacred mushroom country (Wasson Wondrous 60)." Cholula, a great ancient ceremonial site, is also near Popocatepetl. It is "only a short distance away in every direction from the teonanacatl and ololiuqui country. Each year in midSeptember when the sacred mushrooms abound the Indians still go on pilgrimage to Cholula and thereabouts (Wasson Wondrous 120)." Here also is where Professor Roger Heim discovered a then new species of mushroom, now called Psilocybe aztecorum Heim that must have been the model for the mushroom emblem found on the statue. According to Wasson the shapes are very close to the same. Wasson believes that the mushroom designs on the body of Xochipilli express a glyph representing any of the many species of entheogenic mushrooms.

The butterfly on the mushroom emblem is perhaps representative of the souls. Butterflies don't feed on mushrooms, but here in this emblem we see a butterfly "feasting on teonanacatl which may have been considered the 
food of the gods, to whose world the mushrooms could transport a person for a brief spell ... (Wasson Wondrous 62).” Fray Toribio de Benavente, also known as Motolinía rendered the word teonanácatl as "god's flesh" and interpreted this as a sacrilege of the Holy Eucharist. Nanacatl he rendered as flesh and teo as god. Wasson has studied worldwide mushroom vocabulary and the Nahua vocabulary is no exception. According to him, nanacatl is built on nacatl. Nácatl is the word for flesh, food, bread, meat, etcetera.

By doubling the initial syllable it assumes a pluralized form that gives to the mushroom a soul, a status unique in the vegetable world. All mushrooms - nanácatl - are endowed with a soul, a unique status granted to the non-hallucinogenic kinds, the divine kinds dominating by their overwhelming importance the whole fungal world. The root meaning, 'flesh,' is emotionally colorless, neutral (like e.g. 'meat,' 'bread', 'cheese' as given above), but it becomes exalted when the plural form - nanácatl - is preceded by teo- or xochi-, the designation of the entheogenic kinds. (Wasson Wondrous 42)

In his Diccionario de la lengua nahuatl o mexicana, Rémi Simeón defines teonanácatl as a small bad tasting mushroom that intoxicates and produces hallucinations. Nanacatl, he simply renders as mushroom.

To further his discussion of teonanacatl, Wasson received a 
communique from a friend of his, Thelma Sullivan, demonstrating to him that teonanácatl means divine or wondrous mushrooms, not 'gods' flesh' as had been interpreted by earlier scholars, such as Motolinía. Teo means divine, wondrous or awesome, not "god" as previously rendered, and nanacatl means mushrooms (Wasson Wondrous 44). This rendering now describes the mushroom as the natives saw it; something wondrous, totally awesome, beyond their comprehension, a wondrous or divine gift from their gods that would transport them to the paradise of the gods.

Also on the statue are two symbols, the tonallo and the tlapapalli. The tonallo, a set of four circles or balls, represents summer, light, warmth from the sun, butterflies, and flowers. The tlapapalli, four vertical strips, which represents along with the tonallo, supreme joy and bliss. According to the ideas that Wasson expresses in his book, theWondrous Mushroom, these symbols seem to reinforce the idea that the expression of ecstacy on this statue is caused by the entheogens.

In Wasson's work regarding entheogens, the flowers on the body of Xochipilli have been studied and identified by Richard Schutes of Harvard University. He, along with his associates and Wasson, has identified most of the flowers carved into the statue. Most of chapter three of Wasson's Wondrous is a description of the carvings on this statue. The following is a summary of the information regarding the carvings. 
On the right haunch is found Nicotiana Tabacum, the common tobacco plant which was an important part of aristocratic gatherings. “ . . . las píldoras de tabaco servían para provocar visiones (Rodríguez 127).” The right thigh has a carving of Turbina corymbosa, the ololiuqui of the Nahua or, as we know it, a morning glory flower which was an important hallucinogen. On the left leg are budding morning glory flowers. The right leg below the knee, the left hip, inside the left calf and the right torso are found Heimia salicifolia, the sinicuichi of the Mexican highlands, a mildly intoxicating plant causing auditory, not visual hallucinations. On the left torso is found the Quararibea funebris, or cacahuaxochitl, a flowered tree which produces the poyomatli flower, a strongly aromatic flower with hallucinogenic properties. This flowered tree is also shown in the Florentine Codex. A copy of this tree can be found on page 69 of Wasson's Wondrous. On the inner calf of the right leg, an unidentified four petalled flower is found. Most likely it is also entheogenic since the rest of the carvings are as well.

The statue itself can be viewed as a chart of entheogens used by the aristocracy in their quest to know the truth, to know the divine. The flowers carved into the statue represent the culture of the Nahua nobles and princes, so only those entheogens appropriate to aristocratic use are used in the carving. An additional observance is that no plants linked with alcoholic beverages are carved. There is nothing representing pulque or maize beer, 
which were not considered aristocratic drinks. The statue of Xochipilli, then appears to be a three-dimensional chart of the divine substances used by the aristocracy.

According to Wasson, this statue represents Rapture. It is an important link between the culture of the nobles and their literature. The flower carvings of the statue serve to confirm this reading, of rapture. The mushrooms and flower carvings amply ratify the identification Wasson has given to Xochipilli, that of the God of Rapture, instead of merely the Lord or Prince of Flowers (Wasson Wondrous 72). "The elegance of this statue, its subtlety, its nobility, speak for the exalted place accorded to the entheogens by the elite in Pre-Conquest Mesoamerica (Wasson Wondrous 72).” The statue of Xochipilli is the embodiment of the supreme image of the flor. Therefore the statue, then, becomes the key to a new interpretation of the literature and other floral artifacts.

The consequences of accepting Wasson's interpretation of Xochipilli, as well as the symbol flor as a metaphor for entheogens, is to commit oneself to a "reappraisal," as Wasson puts it, of Pre-Conquest Mesoamerican culture and more specifically for us, a re-evaluation of the term flor in the literature.

Angel Garibay and Miguel León-Portilla have done a tremendous work with Pre-Conquest Literature. They have very carefully translated, compared and studied the ancient texts. They should be credited for resurrecting this 
body of literature, bringing it to our attention and for making it an important part of the modern study of Mesoamerican literature. In all their study, they make only a very few references to the use of entheogens. They do not raise questions as to why flor symbolizes true/divine words or poetry. Although they admit the use of entheogens among the nobles in the Pre-Conquest cultures, they do not connect this use to the literature that these same nobles created and performed. They admit the use of entheogens by the nobility at religious rites and ceremonies, but they fail to connect the entheogenic experience to the songs that the nobility sang at these same rites and ceremonies under the influence of entheogens.

Since we now are aware of an additional possible rendering of the metaphorical meaning of flor, we must focus on the literature itself and apply this new connotation of the metaphor to the poems and songs. It is hoped that a much more profound reading will be rendered. We will be studying various poems, including religious hymns and lyric poetry.

Flowers are frequently mentioned in the Nahuatl songs or poems. The Nahua nobles were obviously overjoyed with flowers and all the prospects that they represented. These painters of poetry, or masters of the spoken word were the well-educated, highly cultured men of the Nahuatl society. They had studied at centers of higher learning for nobles, calmecac, and were well-versed in the traditions of the people. At the calmecac they were 
educated in philosophy, theology, rhetoric of the nobility, history, music, physical education, sciences, work ethics, codes of conduct, morals, values and traditions, and doctrines and precepts of religion (Diaz Infante 34-42). These nobles were the leaders of their communities and led very disciplined and orderly lives according to the customs of the people. They were seekers of truth and seekers of the divine. The "flowers," or entheogens, were the avenue they took to find this truth, to touch the divine. Their songs were an outpouring of their mystical experiences aided by entheogenic visions.

The flowers took them to another world where they sang their Aztec poetry to the music of their Aztec instruments, a world that they called their Tlalocan (or sometimes their Tamoanchan), a world of strange and wondrous beauty, where they reveled in sensations beyond imagining. It is not surprising that these Princes and Nobles, able and sophisticated men, composed poetry weighted with flower. (Wasson Wondrous 79)

The mystical experience through the use of entheogens was one of the most meaningful experiences in the Nahua poet's life. To touch truth, to touch the divine was one of his highest aims. For him this entheogenic adventure was the treasure-chest of divine or true words. "The entheogenic experience was the supernatural event of their lives and it supplied them with a storehouse whence they drew their ultimate in verbal praise, redolent with 
religious feeling (Wasson Wondrous 81)." The supernatural event of their lives was made possible through the use of flowers, or the plants endowed with mystical powers, entheogens. These were considered a gift from the gods to be used to commune with the gods. "They were dealing with a miraculous, a divine gift (Wasson 81).”

The Nahuatl poets, having often penetrated that 'beyond,' are on the other hand awestruck by its overwhelming impact on all their senses, on their emotional being, by the certainty they feel that they have here touched base with Truth, by the further question it poses for them about the Absolute and the Ultimate, and by the extraordinary feelings of friendship that it breeds among those who have shared in the common experience.

(Wasson Wondrous 82)

Some of the themes common to many of the poems include questions and thoughts on truth, life and the shortness of life, the mystery of the divine, and friendship. These themes of profound thought are explored by the nobility by means of the plants endowed with mystical powers, the entheogens. Among the most common of the metaphors used in these poems, created under the divine influence of the psychotropes, include the metaphors flor, birds, butterflies, and precious stones (jade) and feathers (quetzal). As has been discussed flor is often a metaphor for entheogens, especially when 
coupled with canto to depict the poetry created under the influence of entheogens.

The first poem we will discuss is a poem by an anonymous poet that begins with a question for the priests. The singer asks where the flowers that inebriate come from. “¿De dónde vienen las flores que embriagan (LeónPortilla Cantos 108)?" The answer is that they come from the god's house from within heaven. " . . de dentro del cielo (León-Portilla Cantos 108)." Where is this heaven? According to Wasson it could be the verdant, lush slopes of the volcano Popocatepetl. "Paradise - their Tlalocan - was situated on the slopes of a verdant mountain to the East and for the Aztecs the towering massif topped by the volcano Popocatepetl was their Tlalocan their Garden of Eden (Wondrous 60)." This was the heart of sacred mushroom country. If we are assuming that flor refers to entheogens then perhaps the singer is referring to the sacred mushrooms when he says they only come from the god's house from within the slopes of Popocatepetl (mushrooms seem to burst forth from within the earth). He goes on to say that the god reigns over the entheogens, they are his delight and they are what makes him happy. "Sobre las flores impera, / se deleita y es feliz (Cantos 108)."

Another anonymous singer says in his poem that his song is entwined with red, fragrant flowers, where the Tree is raised up or built. "Mi canto está entrelazado de rojas y olientes flores, / en donde se yergue el Arbol ( 
115)." Evidently there were occasional gatherings around the Arbol Florido, a symbolic tree that was constructed for certain ceremonies. Wasson, as well as Durán, mentions a tree being erected and laden with flowers on the feast of Xochipilli. Perhaps it is this tree or a similar one that is referred to here. At any rate, the singer is perhaps referring to entheogens when he mentions the flowers that are entwined with his song. His song is a result of the inebriating experience he has enjoyed due to the flowers. Thus the intertwining relationship between flowers and song.

In the same poem the singer mentions the use of mixed cacao, "Se hace el baile con el cacao mixturado (Cantos 115)." This was a common practice at the gatherings of the nobles. They would dance, sing their songs (poems), and drink a chocolate beverage.

This saying was said of cacao, because it was precious.... The common folk, the needy did not drink it ... it was considered to be like the mushroom [nanácatl], for it made one drunk; it intoxicated one. If he who drank it were a common person, it was taken as a bad omen. And in times past only the ruler drank it, or a great warrior, or a commanding general, a general. If perhaps two or three lived in wealth, they drank a limited amount of cacao, for it was not drunk unthinkingly. (Sahagún Florentine Bk 6 256) 
The chocolate beverage also was mixed with the flowers of the xochicacahuatl (Quararibea funebris). The flowers of this tree were known as poyomatli. They had a powerful, long-lasting fragrance and were considered hallucinogenic. These flowers were mixed with chocolate to create the drink that, according to Wasson, accompanied the ingestion of the sacred mushrooms (Wasson Wondrous 88). Tobacco, although not mentioned in this poem, also played an important part at such gatherings and also seemed to be esteemed for mild psychoactive powers.

Later the singer continues his song praising the god because the flowers are now available. He mentions flowers that shine like the sun. "Las flores de primavera ya relucen como sol (Cantos 115)." There are mushroom varieties that are red, orange or golden that may remind one of the shining sun. There are also varieties that glow in the dark, thus shining like the sun or moon (World Book 941). He even says that some of the flowers are the heart and the flesh of the god. He could be referring to the teonanácatl; the essence of the god. They are the worldly manifestation of the god - his gift so that man may know his heart.

Subsequently he poses the question, “QQuién no quiere tus flores...?” The obvious is that all the nobles want these precious, and highly esteemed flowers, for it is through them that they are able to practice their high art of creating meaningful song with words of truth. 
The singer of the next poem has been to the god's house. He is either referring to the hallucinogenic experience he has just had or he is referring to an actual trip to the slopes of Popocatepetl, where he gathers the "flowers," the entheogens. He praises the flowers that entrance or enrapture. This is not a figurative trance or state of rapture, but a very literal one. The inebriation is real. His song comes from this inebriating experience. He gives the world his flowers, referring to the divine words he has composed, or the words made possible through the entheogenic experience, and the truth and the divinity he has touched through his entheogenic experience.

Yo de su casa vengo,

las flores que embelesan elevo:

¡es el canto!

Yo doy al mundo mis flores. (Cantos 115)

At the conclusion of the poem, again through his carefully chosen, true words, the noble is praising the fact that he has flowers. We see that the noble gives ownership of the flowers to the god. It is the god that opens up the flowers. The god causes the mushrooms to burst out of the ground. The god is in control of nature, it is his. We are reminded that by ingesting the entheogens, the noble is reaching out into the realm of the deity. Through the entheogens he experiences communion with the divine. It is reasonable then for the noble to see the god as the controller of the "flowers," as the owner who 
gives them as gifts to man.

Bébase la miel de ellas,

o preciosas flores y olientes se esparcen:

son las flores de él, las abre el dios,

que en su casa flores de niebla

yo tomo... ( $\underline{\text { Cantos } 116)}$

Perhaps the most well-known Nahua composer of song (poetry) today, as well as in his day, is Nezahualcoyotl [1402-72]. This Nahua ruler was not only a great ruler and warrior, el guerrero sin igual, but also a very wise counselor, a just but also merciful judge, an astrologer, a great engineer and designer. He created elaborate gardens, designed a water system that brought fresh water from Chapultepec to his royal city, Texcoco, on the other side of Lake Texcoco, and established the first library of the New World complete with various manuscripts and codices. For his cultural achievements he has been called the Pericles of ancient Mexico and for codifying the laws of Texcoco, the Hammurabi of the New World (Durán Aztecs 338).

[Nezahualcoyotl was] famed as a statesman, philosopher, poet and hydraulic engineer.... He demonstrated his military and political abilities by forming the alliance and conducting the war. Under him, Texcoco gained its reputation as artistic center of the 
empire. He designed his gardens at Tetzcotzingo, and he advised the Mexica on the construction of Chapultepec and of the great dike east of Tenochtitlán, that controlled floods and separated saline from fresh water. (Rodríguez 307)

He was a chief philosopher of his day that sought after truth, and a free thinker, for much of his philosophy, especially regarding religion was an open contradiction to the priests of his day (Vigil Nezahualcoyotl 157). Baudot refers to Nezahualcoyotl as the Mexican Homer, "es un poco el Homero mexicano (55)." His radical religious thought included the idea of one omnipresent, omniscient, invisible god of which there could be no image made and that did not require the blood sacrifices of the Aztec pantheon. He built and dedicated a temple to this god and devoted himself to this sustainer god that listened to prayers and received souls. His open, monotheistic beliefs in the invisible god, Tloque Nahuaque, directly contradicted the Religion of the Aztec empire.

Nezahualcoyotl was a forjador de cantos. His cantos show the very profound thoughts of a great philosopher, as the Mexican Homer he is described as being. Daniel Brinton collected his information about Nezahualcoyotl from Fernando Alva Ixtlilxochitl's Historia Chichimeca and from Joseph Joaquín Granados' Tardes Americanas.

Nezahualcoyotzin, an enlightened ruler of Tezcuco, about 1450, 
was both a philosopher and a poet, and the songs which he left, seventy in number, some of which are still preserved, breathe a spirit of emancipation from the idolatrous superstition of his day. He announced that there was only one god, who sustained and created all things and who dwelt above the ninth heaven, out of sight of man. No image was fitting for this divinity, nor did he ever appear bodily to the eyes of men. But he listened to their prayers and received their souls. (Brinton 246-7)

In Nezahualcoyotl's song entitled "Solamente él," we catch a glimpse of the thoughts of this philosopher-king as he is talking to the Dador de la vida. He opens the poem discussing the vain wisdom that he has had compared to that of the Giver of Life. His true happiness hasn't been with people, but with the Giver of Life. Precious realities or truths come from the Giver of Life. As Nezahualcoyotl says, the Giver of Life causes these precious truths to rain. "Realidades preciosas haces llover (León-Portilla Trece poetas 86)." We are reminded that the entheogens were the path to the divine, where truth could be sought. Then we see the strong longing that Nezahualcoyotl has for the precious, fragrant entheogens. "Olorosas flores, flores preciosas, / con ansia yo las deseaba, / vana sabiduría tenía yo ... (Trece poetas 86)." The wisdom that he naturally has pales to that which he gains through the entheogenic experience and pales to that of the god. He longs for the flores preciosas 
because he longs for the truths he gains from the divine by means of the flores. The theme of another poem by Nezahualcoyotl is quite different. It is entitled "Alegraos." The focus is happiness. He is spurring others on to happiness through "flowers" (entheogens). He is telling them to be happy, to cheer up with the "flowers" that intoxicate, the ones that they have in their hands and wear around their necks.

Alegraos con las flores que embriagan, las que están en nuestras manos.

Que sean puestos ya

los collares de flores. (León-Portilla Trece 87)

We find that carrying flowers in the hands and wearing flowers around the neck were common practices. Durán mentions flowers and garlands as being part of the feast of Tezcatlipoca. Even the impersonator of the god was so adorned (Durán 132). Many times throughout his work, Durán mentions the importance of flowers, bouquets and garlands at various festivals and ceremonies. He even states that "they [the Nahuas] passed their lives among flowers (Durán 238)." We can now appreciate why Durán wrote this observation. The flowers were the connection between the noble believer and the divine.

Nezahualcoyotl next mentions the flowers from the time of rain. "Nuestras flores del tiempo de lluvia, / fragantes flores, / abren ya sus corolas 
(Trece 87)." We are suggesting here that he may be referring to the teonanacatl that spring up out of the ground after a time of rain. According to Wasson, Garibay's rendition “abren sus corolas" is not the most accurate interpretation of the Nahuatl word, cueponi, that reoccurs often in the poems. It is better rendered as "bursting forth," thus supporting the contention that the poet is indeed referring to teonanacatl, the divine mushroom that bursts out of the ground after a rain.

In Molina's lexicon the first meaning of cueponi is to burst forth as a chick from an egg. The second meaning is to burst open as a chestnut when it is roasted.... Only the third rendering covers the flowers that emerge from their buds. If my reading of the statue of Xochipilli is right, if xochinanácatl means what Molina says it means, if my meaning for 'flowers' is right, then the meaning in the poetry of the Nahua of cueponi must be the bursting forth of the divine mushrooms from the 'egg' that marks their first appearance on the earth. And as we all know, at first they do look like eggs, round and white, and they do burst forth overnight. ... Cueponi occurs so frequently and cueponi fits the mushroom world so nicely that it is as if made to order for my argument. (Wasson 85)

The poet ties the bursting forth of the "flowers" to the rainy season. 
This is exactly nature's way. The mushroom gatherers sally forth after a drenching rain to harvest their precious commodity. Whether entheogens, edibles or poisonous, after a rain, the mushrooms burst forth from the earth to stand upright, without roots. This is the phraseology that is repeated throughout Nahuatl poetry: flowers that burst forth, flowers without roots. The Nahuas were observers of nature. They were observers of mushroom growth and reproduction and their songs reflect this.

Further on in the poem, Nezahualcoyotl states that we are only happy with our "flowers," meaning entheogens. We only lose our sadness with our songs, the songs that are a result of the entheogenic experience provided by the "flowers." "Sólo con nuestras flores / nos alegramos / Sólo con nuestros cantos perece vuestra tristeza (León-Portilla Trece 87).”

To end his poem Nezahualcoyotl proclaims that the Giver of Life, who creates himself, also creates the pleasant "flowers," again referring to entheogens, which cause one's sorrows, displeasures and troubles to vanish. The entheogens and 'flores placenteras,' responsible for the ecstatic state and visions, cause the troubles to vanish. Under their influence the singer is able to rejoice.

Las inventa el Dador de la vida, las ha hecho descender el inventor de sí mismo, 
flores placenteras,

con esto vuestro disgusto se disipa. (Trece 87)

"Poneos de pie" is a poem of exhortation by Nezahualcoyotl to his

friends. He is encouraging them to take their flowers and their fans and dance. "Toma ya tus flores y tu abanico. / ¡Con ellos parte a bailar (Trece $80) ! "$ He encourages them to take their chocolate drink and dance and compose songs. "Toma ya tu cacao, / la flor del cacao, / „que sea ya bebida (Trece 80)!" As was mentioned earlier in this work it was a common practice among nobles to drink a chocolate beverage laced with narcotic flowers at their gatherings. This would enable the nobles to create songs under divine influence. Nezahualcoyotl is encouraging his friends to drink theirs and participate in the festival by dancing and composing.

Another well-known Nahua ruler, sage and poet, Tecayehuatzin, mentions flores de cacao in his poem "iCantemos ya!"

Con flores de cacao, exclama y viene veloz, allá con flores se alegra en el interior de las aguas. (Trece 202)

Flores de cacao, is again referring to the chocolate beverage that was customary for the nobles to take during their gatherings. Tecayehuatzin is also saying that with flowers one becomes happy, or perhaps, at least, mildly 
inebriated. The phrase "en el interior de las aguas" could be referring to the relationship that water and divine mushrooms have, or to Tlalocan, the place of Paradise. Another way of interpreting this phrase would be to imagine an infusion of the entheogenic flowers and water that the noble would ingest to produce his divine visions. Tecayehautzin mentions flowered adornments and the flowers that inebriate, the entheogens.

In a larger dramatic work entitled "Bailete de Nezahualcoyotl," is an interesting portion subtitled "segundo tiempo: Monólogo de Nezahualcoyotl (Garibay La Literatura 84)." This seems to be a song filled with praise and pleasure due to flowers of various kinds. The singer says that he takes flowers that inebriate as well as those that are fragrant. "Tomo las flores que embriagan, / también hay flores de aroma! (Garibay 84)" Singing and dancing, as well as flowers, are once again an important part of this poem. The singer is rejoicing because the bunches of flowers have arrived and not just any flowers, but the flowers of pleasure, the entheogens. "Llegaron ramilletes de flores: / son las flores del placer: (Garibay 84)" He encourages the others to take the flowers, to enjoy.

The chorus of a poema dramatico sings a poem that is very interesting to our theme. The poem comes from the third part of "Huida de Quetzalcoatl," subtitled “diálogo de cantores," (Garibay Literatura 97). The song expresses thoughts about the singer and the flowers. The flowers are 
precious and fragrant. They are raining narcotic flowers, or flowers with psychoactive capabilities. The singer says his song is heard to germinate and the words of his sowing are now sprouting. The vocabulary used is representative of nature and the growth of flowers and mushrooms. He concludes the song by proclaiming that in this time of rain our flowers are already standing upright, referring to entheogenic mushrooms ready for harvesting.

Pero las preciosas flores

fragantes vienen abriendo:

exhalan su aroma y llueven

las flores narcotizantes, allí vivo y ando yo, que soy cantor.

Se oye germinar mi canto, las palabras de mi siembra ahora retoñando están:

ya se yerguen nuestras flores

en este tiempo de lluvias. (Garibay Literatura 97)

An additional song attributed to Nezahualcoyotl in an article, "The spell of the Hungry Coyote: Fragments of Nezahualcoyotl” by Frank Chapman, is entitled the "Sacred Drink Teonanacaoctli." I have only found this rather awkward English rendering by Mr. Chapman. In this song, 
Nezahualcoyotl is lamenting his miserable state here on this earth.

A feeling of sorrow

Oh, I drank the wine of the mushrooms

Gulped it down

Swallowed the fungus beer

And my heart

Oh, the crying!

A bitterly suffering me, I

Made.

Oh, just a miserable man, I

Am, on this earth. I

Myself to meditate

On me not enjoying life

On the not happy me here.

I remember your plan

Our design

And stop being troublesome.

Here are your flowers! (Chapman 380)

The noble, in this case Nezahualcoyotl, is expressing his deepest thoughts about life here on this earth. Since it was customary to do so, we assume that he has ingested an entheogenic substance in order to go beyond 
his earthly state, in which he obviously is unhappy, and experience the realm of the divine. It is there that he will not be troubled by the cares of the world. Perhaps he has written this in a rather awkward, disjointed manner as if to reflect an intoxicating experience. At the end of the poem he takes his sight off the troubles of this world and onto the plans and flowers of his god and is no longer troubled. He makes an offering of flowers, either referring to the entheogens he has taken, or referring to the divine words he has composed as a result of ingesting the divine flowers.

Death and the brevity of life are also common themes throughout Nahuatl poetry. "Frecuentemente también el poeta pinta vivamente la brevedad de la vida, la vanidad de los goces humanos, que lanzan sus resplandores, y que deben morir algún día (Rodríguez 111).” In these poems, the singer does not always mention the flowers that intoxicate, but we shall keep in mind that the songs were composed and delivered at the very least under the influence of pipes of tobacco and the foaming cups of chocolate mixed with psychoactive flowers, if not more powerful entheogens.

In "Percibo lo secreto..." Nezahualcoyotl laments the fact that we are mortals, that we all have to go away, that we all have to die (Literaturas 152). “Todos habremos de irnos, / todos habremos de morir en la tierra (Literaturas 152)." He exhorts the lords and warriors to meditate on this theme, because all will disappear, no one will be left. The only direct reference he makes to 
flor is when he likens the human existence here on earth to a drying flower. "Como una flor / nos iremos secando / aquí sobre la tierra (Literaturas 152). The ecstatic state of the poet has this time caused him to ponder deeply the idea of death.

"Estoy embriagado..." is another lament that death and disappearance from this earth is destined (Literaturas 153). The singer opens the poem by exclaiming that he is inebriated, we are assuming that this is a literal, as well as a figurative intoxication, brought on by the entheogenic substances he has ingested in order to seek the divine truth ahout the afterlife. The singer does express hope, however, in the hereafter. He believes that after this life one goes to a place where there is no death, in fact, where death has been conquered. This entheogenic experience has allowed this poet to consider what the afterlife may be like.

Estoy embriagado, lloro, me aflijo, pienso, digo, en mi interior lo encuentro: si yo nunca muriera, si nunca desapareciera.

Allá donde no hay muerte, allá donde ella es conquistada, que allá vaya yo... 
Si yo nunca muriera,

si yo nunca desapareciera. (Literaturas 153)

"Muerte fatal" is an anonymous song from Tenochtitlan. It has quite a melancholy tone. The lament is that there is no escape from death, but in this same statement the singer encourages the others because no one escapes the inevitability of death, afterall death is a part of the human existence we call life.

¿A dónde iremos que muerte no haya?

Por eso llora mi corazón.

¡Tened esfuerzo: nadie va a vivir aquí!

Aun los príncipes son llevados a la muerte:

así desolado está mi corazón.

¡Tened esfuerzo: nadie va a vivir aquí! (Garibay Literatura 60)

Death, the hereafter and the transitory nature of life are the themes of the next song, "Hemos venido solamente a marchitarnos (Garibay Literatura 69)." The singer poses a series of questions dealing with death and the afterlife. He wants to know if there is life after death and are we conscious beings after death? Do we recognize friends and family in this new state of consciousness?

¿Es que sigue habiendo vida en el lugar del misterio? ¿Es que aún tienen allá conciencia nuestros corazones? 
¿Habré de verlos acaso?

¿Veré a mi padre y mi madre? (Garibay Literatura 69)

In his entheogenic voyage the singer explores questions about the afterlife that seem fairly common, even to modern man. He composes his song with the questions that are on his heart, the questions that will possibly be answered in an encounter with the divine.

In "Enigma de vivir," an anonymous poem from Chalco, the singer points out that we do not continue on here on this earth. He laments that he must leave the beautiful flowers, the entheogens, and go looking for the place of mystery - the afterlife. He ends his song on a brighter note that at least for a short time, let's compose beautiful songs, as always as the customary practices allow, under the influence of entheogens.

No es verdad que vivimos, nos es verdad que duramos en la tierra.

¡Yo tengo que dejar las bellas flores, tengo que ir en busca del sitio del misterio!

Pero por breve tiempo, hagamos nuestros los hermosos cantos. (Garibay Literatura 57) Another song, "Vida falaz," attributed to Nezahualcoyotl exclaims that we are here for only a moment. Everything, no matter how precious, will 
eventually perish. Through this poem, and the entheogenic experience that allowed him to create it, he ponders the brevity of life. The transitory nature of life is the focus of this singer's thoughts as he gathers divine words through his entheogenic experience.

¿Es verdad, es verdad que se vive en la tierra?

¡No para siempre aquí: un momento en la tierra!

Si es jade, se hace astillas, si es oro, se destruye;

si es un plumaje de quetzal, es rasga.

¡No para siempre aquí: un momento en la tierra! (Garibay Literatura 63)

A song with somewhat of a different outlook on the situation of the shortness of life is "La vida pasa: Hay que vivir." This anonymous composer expresses the idea that since we're here on earth for such a short time, let's enjoy life to the fullest, bring on the flowers [the entheogens]. Our songs, the flowers [entheogens] and the earth will be left behind, but we will continue on in a place where our existence goes on.

No por segunda venimos a la tierra, príncipes chichimecas.

Gocémonos y traíganse las flores.

¡Al Reino de la Muerte! . . s sólo estamos de paso: 
¡de verdad, de verdad nos vamos;

¡Verdad es que nos vamos!

Verdad es que dejamos las flores y los cantos, y la tierra ... iEs de verdad, de verdad nos vamos!

¿A dónde vamos? ¿A dónde vamos?

¿Estamos allá muertos o aún tenemos vida?

¿Hay sitio en que dura la existencia?

¡En la tierra tan sólo

es el bello cantar, la flor hermosa:

es la riqueza nuestra, es nuestro adorno:

gocémonos con ella! (Garibay Literatura 66)

This singer has displayed quite a fatalistic tone and an Epicurean philosophy in his song. Entheogens are the enjoyment of life here on earth, so the singer encourages the others at this gathering to seek the pleasures of life to "eat, drink and enjoy, for tomorrow we die." He encourages his friends to take advantage of the present without regard to the future, carpe diem.

A poem of Tochihuitzin, "Vivisteis el canto," is in itself, a metaphor for flor $y$ canto. Tochihuitzin is a weaver of grama, a medicinal grass (also halucinogenic?). The wise ones or the princes have dressed themselves in song and have opened the flower. In other words they have partaken of the flower(s) which stands for all the sacred, psychoactive plants used at this 
time. They have become song incarnate. They are dressed in song. The song is the outpouring of their souls as a result of their "flowery" experience. Their entheogen induced states have made possible their series of divine songs.

$$
\begin{aligned}
& \text { Vivisteis el canto, } \\
& \text { abristeis la flor, } \\
& \text { vosotros, oh príncipes, } \\
& \text { yo, Tochihuitzin, soy tejedor de grama, } \\
& \text { el sartal de flores } \\
& \text { por allá cae. (León-Portilla Trece 145) }
\end{aligned}
$$

Very few women poets are included in the collections of poetry that have survived the centuries. Macuilxochitzin is one such poetess. She was the daughter of the noble statesman and adviser to the throne, Tlacaelel [d. 1480]. As a daughter of the nobility she too would have been educated in the finest schools of the empire for girls, an annex to the calmecac (Diaz 71). There she would have learned the customary role of a noble Aztec woman. “Aquí aprendían reglas morales y las maneras en que tenían que cumplir su papel social (Díaz 72)." The poem chosen for analysis is "Canto de Macuilxochitzin (Trece 179)." In this poem Macuilxochitzin wishes to preserve the memory of her people's victory against a rival tribe. She offers praise and thanks to the (a) supreme god of the Aztecs, the Giver of Life. She urges the commencement of the dance in order for her history of the battle to 
begin. In the middle of her song flor and flor $y$ canto become an increasingly important part of her discourse. Slowly, flower and feathers, which are both established precious offerings to the gods and warriors, are offered to the Giver of Life. Macuilxochitzin relates the joy that Axayácatl, the warrior-king of the Aztecs, has brought to the Giver of Life through this victory to the joy that their songs and flowers also give to the Giver of Life.

Como nuestros cantos, como nuestras flores, así, tú, el guerrero de cabeza rapada, das alegría al Dador de la vida. (Trece 180)

The flowers received as tribute for the high rank of eagle warrior remain in his [Axayácatl's] hands. He retains the leadership and the highest rank among the warriors, as well as the people. "Las flores del águila / quedan en tus manos, / señor Axayácatl (Trece 180).”

Not only with the divine sacred psychoactive flowers, but also with the flowers of war, the psychoactives are given to warriors to cause them to fight more fiercely and bravely, even fearlessly. Even the lowly peyotl was used in war. " ... comida o bebida en decocción, sumerge al individuo en la embriaguez por dos o tres días ... da valor en el combate y los hace insensibles al hambre y a la sed (Rodríguez 4).”

Con flores divinas 
con flores de guerra

queda cubierto,

con ellas se embriaga

el que está a nuestro lado.

Sobre nosotros se abren

las flores de guerra

en Ehcatépec, en México,

con ellas se embriaga

el que está a nuestro lado. (Trece 180)

Ayocuan was a poet from the Puebla region of Mexico. His poem "Las flores y los cantos" deals with some common themes among the Nahua poets, that of friendship, vanity and the brevity of life. The poet expresses his thoughts that from the divine, the interior of heaven, come the beautiful flowers and songs. "Del interior del cielo vienen / las bellas flores, los bellos cantos (Trece 213).” It has also been suggested earlier in this study that "interior del cielo" may refer to the sacred mushroom areas of the sacred mountains, especially in the Puebla region of Mexico. At any rate, whether either a terrestrial or an extraterrestrial place is meant, it is still considered to be a most holy place from whence the divine verses come. Flor y canto, or the songs and verses that come from the sacred psychoactives, lives on in the house of the Giver of Life. 
Ayocuan likens friendship to a rain of precious flowers. This metaphor of friendship elevates it to a very high place in Aztec thought. Flowers are very special, highly sought after gifts from the gods, and here Ayocuan says that friendship is just as important. Another interpretation of the rain of precious flowers could be that Ayocuan enjoys the flowers so much that he wants to share them as gifts to his friends. Friends sharing the precious flowers makes their bonds of friendship stronger. "La amistad es lluvia de flores preciosas (Trece 213).”

On the inanity of man and his creations, the poet poses some questions. Am I only here to perish like the flowers? Will nothing of my name or my reputation remain? He expresses a tone of futility and emptiness toward the vanity of one's life here on earth. His lamenting tone is much like that of the Jewish King Solomon in the book of Ecclesiastes and in "Las coplas por la muerte de su padre" by Jorge Manrique. He expresses that at least we have our precious flowers and the verses that they help us create.

¿Sólo así he de irme

como las flores que perecieron?

¿Nada quedará de mi nombre?

¿Nada de mi fama aquí en la tierra?

$¡ \mathrm{Al}$ menos flores, al menos cantos!

¿Qué podrá hacer mi corazón? 
En vano hemos llegado,

hemos brotado en la tierra. (Trece 213)

The poet's tone brightens when he ponders the friendship that one finds here on earth and that fact that the songs and verses and the divine force $(s)$ that helped create such songs will not perish, but will continue on in the house of the Giver of Life. The poet realizes that here on earth is the region of the fleeting moment and that eternity is in the house of the Giver of Life where the precious flowers and songs will endure.

Gocemos, oh amigos, haya abrazos aquí.

Ahora andamos sobre la tierra florida.

Nadie hará terminar aquí

las flores y los cantos, ellos perduran en la casa del Dador de la vida.

Aquí en la tierra es la región del momento fugaz. (Trece 214)

In this study an additional rendering of the metaphor for flor and flor $y$ canto has been explored and applied to some of the Pre-Conquest Nahuatl literature. As a basis for the theory presented in this study, that flor and flor $y$ canto not only refer to the poetry created by the nobility, but also to the entheogenic flor that created the visions where he received his poetic inspiration, we have looked at Pre-Conquest religious practices and pertinent 
archeological treasures. Sahagún's native informants' testimonies have been very valuable as a basis for knowledge about the Aztecs. Through the works of Sahagún, Durán, and Caso we have found that Religion so pervaded the Pre-Conquest Nahuatl society that it basically had total control of the society and dictated the Nahua's every move. We therefore found that an important focus of the Nahuatl nobility was to meditate on the divine and show this meditation or devotion through the true words that they were given during their meditative experiences. The rhetoric used by the nobility for their meditations was richly poetic, imaginative and filled with metaphors that are elusive to those not well-versed in the rhetoric of the nobility. We found that these experiences were aided by the use of various entheogenic or psychoactive compounds so abundantly found in the plethora of plants and fungi known to Pre-Columbian Mesoamerica. Of the many then known entheogenic substances teonanacatl, ololiuqui, poyomatli, tobaco and cacao seem to be the preferred entheogens by the aristocracy. The use of these substances was permitted only on certain occasions and they were not for general public or recreational use. As the noble underwent an entheogenic experience, he was transported from the real world via magical flight to the ethereal world of mystical time, space and knowledge. It was there on a search for truth that he would gain wisdom from the divine and be able to express this wisdom through true or divine words in xochitl in cuicatl. 
The most pertinent of the archeological evidence studied is the statue of Xochipilli which, through Wasson's study was found to be a threedimensional chart, so to speak, of entheogenic plants and fungi that the nobility used for their mystical encounters with the divine. This statue also shows an ecstatic expression that could possibly be due to its carved entheogens. The expression indicates a state that would carry one beyond the everyday world to a place of divine ecstacy. He seems to be absorbed by temicxoch, the Nahuatl that describes the divine ecstacy that follows ingestion of entheogens (Wasson Wondrous 58). The statue of Xochipilli, known by many as the Prince of Flowers, or the God of Music and Dance, actually represents Rapture. The flowers carved on the statue support the reading of the expression as rapture. Xochipilli then becomes a key figure in determining that flor is a metaphor for entheogens and the divine words that are produced during an entheogen induced episode of rapture.

Having thus explored an additional meaning of the metaphor, it was then applied it to various Pre-Conquest poems. Even Tecayehuatzin's conference to discuss the true meaning of flor $y$ canto was not able to come up with any one rendering of the metaphor. However this study shows it to be an adequate rendering of the word flor in several of the poems.

Some of the more important themes common to many of the poems studied are the mystery of life, philosophical questions and the importance of 
friendship.

Perhaps the most important Nahua composer known today was

Nezahualcoyotl, whose monotheistic religious thoughts were well outside the mainstream of religious thoughts of his day. We were able to see that his poems reflect the profound thoughts of a great philosopher. He shows concern about the afterlife, the brevity of this life, true happiness and friendship, and his delight in the Giver of Life and the precious flowers that inebriate.

As was commonly practiced among the aristocracy, the songs (poems) were composed and performed under the influence of mildly hallucinogenic tobaccos and foaming cups of chocolate mixed with entheogens. Many of the songs speak of and even praise the flowers that intoxicate, while other do not. Some of the poems studied in this work made no mention of the metaphor flor, but were included because all poetry was considered by the Nahua to be divine or true words, revelations from the divine, influenced by the entheogens that flor represents.

It is hoped that this study has at least opened up the possibility of other interpretations of the metaphor flor and flor $y$ canto; that flor not only refers to true words, as León-Portilla claims, but also refers to the entheogens and the entheogenic induced mystical visions where the noble received the divine true words of his songs. 


\section{Works Cited}

Baudot, Georges. Las Letras precolombinas. México: Siglo Veintiuno, 1979.

Bierh orst, John. Cantares mexicanos Songs of the Aztecs. Stanford: Stanford UP, 1985.

Brinton, Daniel G. American Hero-Myths. Philadelphia: Watts, 1882.

Carrasco, David. Religions of Mesoamerica. San Francisco: Harper \& Row, 1990.

Caso, Alfonso. La religión de los aztecas. Mexico: Secretaría de Educación Pública, 1945.

Chapman, Frank. "The spell of the Hungry Coyote: Fragments of Nezahualcoyotl." Arion: A Journal of Humanities and the Classics. 9.4 (1970): 379-87.

Cortés, Hernán. Cartas de relación. México: Porrúa, 1988.

Díaz Infante, Fernando. La educación de los aztecas. México: Panorama Editorial, 1988.

Durán, Diego. Aztecs: the History of the Indies of New Spain. Trans. Doris Heyden and Fernando Horcasitas. Introd. Ignacio Bernal. New York: Orion, 1964.

-.. Book of the Gods and Rites and the Ancient Calendar. Trans. \& ed. by Fernando Horcasitas and Doris Heyden. Norman: U Oklahoma P, 1971. Easby, Elizabeth Kennedy and John F. Scott. Before Cortés. New York: 
Metropolitan Museum of Art, 1970.

Edmonson, Munro S., ed. Sixteenth Century Mexico. Albuquerque: U NMex P, 1974.

Garibay, Angel M. Historia de la literatura nahuatl. México: Porrúa, 1953.

-... La literatura de los aztecas. México: Joaquín Mortiz, 1978.

Gruzinski, Serge. Painting the Conquest. Trans. Deke Dusinberre. Paris:

Flammarion, 1992.

Hernández, Natalio and Librado Silva. flor y canto [sic]. México: El Día en Libros, 1990.

Klor de Alva, J. Jorge. "Language, Politics and Translation: Colonial

Discourse and Classical Nahuatl in New Spain." The Art of

Translation. Ed. Rosanna Warren. Boston: NEUP, 1989. 143-162.

-...SSagahún and the Birth of Modern Ethonography: Representing,

Confessing, and Inscribing the Native Other." The Work of Bernardino de Sahagún. Ed. J. Jorge Klor de Alva, H. B. Nicholson and Eloise Quiñones Keber. Albany: IMS, 1988. 31-52.

León-Portilla, Ascensión H. de, ed. Estudios de linguística y filología nahuas. México: UNAM, 1977.

León-Portilla, Miguel. Cantos y crónicos del Mexico antiguo. Madrid: Historia 16, 1986.

-.. Literaturas de Mesoamérica. Mexico: SEP Cultura, 1984. 
… Pre-Columbian Literatures of Mexico. Trans. Grace Lobanov \& Miguel

León-Portilla. Norman: U Oklahoma P, 1986.

-... "The Problematics of Sahagún: Certain Topics Needing Investigation."

Sixteenth Century Mexico. Ed. Munro S. Edmonson. Albuquerque: U

NMex P, 1974. 235-255.

López Austin, Alfredo. “The Research Method of Fray Bernardino de Sahagún:

The Questionnaires." Sixteenth Century Mexico. Ed. Munro S.

Edmonson. Albuquerque: U NMex P, 1974. 111-149.

... "Sahagún's Work and the Medicine of the Ancient Nahuas: Possibilites for

Study." Sixteenth Century Mexico. Ed. Munro S. Edmonson.

Albuquerque: U NMex P, 1974. 205-224.

Nicholson, Irene. A guide to Mexican Poetry. Mexico: Minutiae Mexicana, 1988.

-.. Firefly in the Night. London: Faber \& Faber, 1959.

Ortiz de Montellano, Bernard R. Aztec Medicine, Health, and Nutrition. New Brunswick: Rutgers UP, 1990.

Ott, Jonathan and Jeremy Bigwood. Teonanácatl. Seattle: Madrona, 1978.

Rodríguez, Luis Angel. La ciencia médica de los aztecas. México: Editorial Hispano Mexicana, 1959.

Sahagún, Fray Bernardino de. Florentine Codex, General History of the Things of New Spain. Trans. Arthur J. O. Anderson and Charles E. 
Dibble. 12 vols. Salt Lake: U Utah P, 1952-70.

Séjourné, Laurette. Burning Water. New York: Vanguard, 1956.

Simeón, Rémi. Diccionario de la lengua nahuatl o mexicana. México: Siglo veintiuno, 1988.

Sullivan, Thelma D. "The Rhetorical Orations, or Huehuetlatolli in Sixteenth Century Mexico." Sixteenth Century Mexico. Ed. Munro S. Esmonson. Albuquerque: U NMex P, 1974. 79-109.

Wasson, R. Gordon. "The Hallucinogenic Fungi of Mexico: An Inquiry into the Origins of the Religious Idea among Primitive Peoples.” Botanical Museum Leaflets. 19.7 (1961): 137-162.

-... "Seeking the Magic Mushroom." Life Magazine. 13 May 1957: 100-129.

-... SOMA Divine Mushroom of Immortality. Italy: Harcourt-Brace, Jovanovich, 1971.

... "The Hallucenogenic Fungi of Mexico." Teonanácatl. Ed. Jonathan Ott and Jeremy Bigwood. Seattle: Madrona, 1978. 65-81.

-... The Wondrous Mushroom. New York: McGraw-Hill, 1980.

World Book Encyclopedia. Vol. 13. Chicago: World Book, Inc. 1992. 941-945. 22 vols. 